\title{
Pembaharuan Hukum Pedoman Pemidanaan terhadap Disparitas Putusan Pengembalian Kerugian Keuangan Negara Akibat Tindak Pidana Korupsi
}

\author{
Kurnia Siwi Hastuti \\ Pengedilan Negeri Wates, D I Yogyakarta,Iindonesia \\ Korespondensi: kurniasiwihastuti@ymail.com
}

\section{Info Artikel \\ Riwayat: \\ Diajukan : : 13 April 2021 \\ Ditelaah : 15 April 2021 \\ Direvisi : 31 Mei 2021 \\ Diterima : 02 Juli 2021}

Kata Kunci :

kerugian keuangan negara; korupsi; pembaharuan hukum; pedoman pemidanaan

DOI:

10.18196/ijclc.v2i2.12294

\begin{abstract}
Abstrak
Adanya disparitas pemidanaan dalam penegakan hukum terhadap tindak pidana korupsi menimbulkan pengembalian kerugian keuangan negara hasil tindakan korupsi tidak maksimal. Pada semester I tahun 2020 hanya sekitar 5 persen kerugian negara yang dipulihkan dari instrumen Pasal 18 Undang-Undang Nomor 31 Tahun 1999 tentang Pemberantasan Tindak Pidana Korupsi. Mahkamah Agung menerbitkan Peraturan Mahkamah Agung Nomor 1 Tahun 2020 tentang Pedoman Pemidanaan Pasal 2 dan Pasal 3 Undang-Undang Pemberantasan Tindak Pidana Korupsi sebagai solusi terjadinya disparitas putusan sekaligus sebagai pedoman pemidanaan guna mengoptimalkan upaya pengembalian kerugian keuangan negara akibat perbuatan korupsi. Namun demikian, implikasi Peraturan Mahkamah Agung Nomor 1 Tahun 2020 belum dapat diketahui analisis kedudukannya terhadap upaya pemberantasan korupsi dan upaya pengembalian aset hasil tindak pidana korupsi kepada negara. Hal ini menarik untuk dikaji guna mendapatkan formulasi kebijakan hukum ius constituendum yang dapat menjamin keadilan sosial bagi seluruh rakyat Indonesia terhadap disparitas putusan pengembalian kerugian keuangan negara hasil tindak pidana korupsi. Penelitian ini merupakan penelitian hukum normatif dengan pendekatan undang-undang yang dianalisis secara preskriptif. Bahan hukum diambil dari perpustakaan dan internet berupa buku-buku serta peraturan perundang-undangan terkait. Persoalan yang dikaji memberikan simpulan yaitu: analisis yuridis pembaharuan hukum pembentukan pedoman pemidanaan dalam Peraturan Mahkamah Agung Nomor 1 Tahun 2020 terhadap disparitas putusan pengembalian kerugian keuangan negara hasil tindak pidana korupsi ialah Peraturan Mahkamah Agung berkedudukan sebagai substansi hukum dalam pemidanaan tindak pidana korupsi yang ditujukan sebagai pedoman penentuan besar kecilnya pidana yang dijatuhkan dengan mempertimbangkan tingkat kesalahan, dampak, dan keuntungan. Terdapat 6 (enam) tahapan pertimbangan pemidanaan dalam PERMA ini. Ukuran pemidanaan telah mempertimbangan aspek ekonomi dalam hukum. Seyogyanya hakim, jaksa, dan penyidik, serta aparatur terkait agar mendalami dan mendukung Peraturan Mahkamah Agung Nomor 1 Tahun 2020 sehingga disparitas putusan tidak terjadi lagi dan pengembalian aset ke kas negara akibat perbuatan korupsi lebih maksimal.
\end{abstract}

\section{Pendahuluan}

Penegakan hukum terhadap korupsi masih menjadi masalah besar di Indonesia. Adanya disparitas pemidanaan menimbulkan pemulihan kembali terhadap dampak kerugian keuangan negara 
hasil tindakan korupsi tidak maksimal. Indonesia Corruption Watch (ICW) menyebutkan bahwa dalam tahun 2019, rata-rata hukuman pelaku korupsi hanya 2 tahun 7 bulan penjara. ${ }^{1}$ Pada semester I tahun 2020, kerugian negara dari praktik korupsi telah mencapai Rp39,2 triliun. Jumlah ini sangat besar apabila dibandingkan dengan vonis majelis hakim kepada terdakwa hanya sebesar kisaran Rp102.985.000.000, serta uang pengganti sebesar Rp625.080.425.649, US\$128.200.000 dan SGD2.364.315 atau sekitar Rp2,3 triliun. Jadi hanya sekitar 5 (lima) persen kerugian negara yang dipulihkan dari instrumen Pasal 18 Undang-Undang Pemberantasan Tindak Pidana Korupsi. ${ }^{2}$

Sebagai negara hukum kesejahteraan, di samping fungsi reguler, Pemerintah Republik Indonesia berkewajiban melaksanakan fungsi pembangunan (developing function) untuk mewujudkan kesejahteraan masyarakat yang merata. Indikator kesejahteraan merata ialah jika tidak ada tindakan koruptif dalam penyelenggaraan negara. Korupsi menjadi penyebab belum terwujudnya keadilan kesejahteraan di masyarakat karena suatu kepentingan aset negara diselewengkan untuk memperkaya orang atau golongan tertentu. Tindakan koruptif masih terus ada dalam penyelenggaraan pemerintahan, terlihat dari jumlah perkara tindak pidana korupsi yang ditangani pengadilan tidak berkurang. Krisis kepercayaan masyarakat terhadap pengadilan sebagai instansi yang menjatuhkan vonis atas perkara korupsi juga belum tuntas karena masih adanya disparitas putusan hakim dalam perkara korupsi.

Untuk mengadili suatu perkara tindak pidana korupsi, perlu tahapan-tahapan persidangan yang harus dilaksanakan. Pembuktian merupakan salah satu tahapan penting dalam persidangan. Salah satu ahli yang dapat dihadirkan dalam pembuktian perkara tindak pidana korupsi ialah Badan Pemeriksa Keuangan (BPK). BPK dapat menentukan ada tidaknya kerugian keuangan negara. Selain BPK, kerugian keuangan negara dapat ditentukan oleh hakim sendiri. Dalam SE KMA (Surat Edaran Ketua Mahkamah Agung) Nomor 4 Tahun 2016 tentang Pemberlakuan Rumusan Hasil Rapat Pleno Kamar MA Tahun 2016 sebagai Pedoman Pelaksanaan Tugas Bagi Pengadilan disebutkan bahwa dalam hal tertentu Hakim berdasarkan fakta di persidangan dapat menilai adanya kerugian negara dan besarnya kerugian negara.

Tahapan persidangan berakhir dengan pembacaan putusan. Hakim yang memeriksa dan mengadili perkara tindak pidana korupsi dapat menjatuhkan putusan atas perbuatan merugikan keuangan negara yang dilakukan terdakwa. Namun demikian, putusan pengadilan dalam perkara korupsi tidak serta merta dapat memulihkan kerugian keuangan negara. Perhitungan besaran jumlah kerugian menjadi hal yang penting dalam pembuktian perkara tindak pidana korupsi di pengadilan. Pemulihan kerugian keuangan negara dengan pengembalian aset dapat dilaksanakan jika putusan yang dijatuhkan telah melalui perhitungan yang sesuai dengan jumlah yang diselewengkan.

Peradilan Indonesia telah menangani banyak perkara korupsi. Namun demikian, menurut Komisi Pemberantasan Korupsi, kerugian keuangan negara mencapai Rp168 triliun sepanjang penanganan tahun 2004 sampai dengan 2019. Apabila tidak dikorupsi, kerugian negara sebesar ini dapat digunakan untuk membangun 195 gedung sekolah dasar. ${ }^{3}$ Laporan Kinerja Mahkamah Agung Republik Indonesia memaparkan bahwa pemulihan aset Indonesia sepanjang tahun 2016 adalah sebesar Rp1,5 triliun, di antaranya aset itu berasal dari 356 perkara tindak pidana korupsi yang ditangani Mahkamah Agung, berupa uang pengganti sebesar Rp647.373.468.339,- (enam ratus empat puluh tujuh miliar tiga ratus tujuh puluh tiga juta empat ratus enam puluh delapan ribu tiga ratus tiga puluh sembilan rupiah). Sementara itu, denda yang didapat ialah sebesar Rp75.956.400.000,- (tujuh puluh lima miliar sembilan ratus lima puluh enam juta empat ratus ribu rupiah). Apabila dibandingkan dengan tahun sebelumnya, kerugian keuangan negara yang diderita sepanjang tahun 2015 akibat tindak pidana korupsi hanya sebesar Rp31.077.000.000.000,- (tiga puluh satu triliun tujuh puluh tujuh milyar rupiah). Dari data

\footnotetext{
1 https://nasional.kontan.co.id/news/ma-terbitkan-PERMA -12020-icw-hakim-yang-tidak-mengikutiharus-ada-sanksi diakses 28-11-2020

${ }^{2}$ https://www.cnnindonesia.com/nasional/20200930124534-12-552660/icw-kerugian-negara-akibatkorupsi-rp392-t-di-2020 diakses 21-11-2020

${ }^{3}$ https://www.medcom.id/nasional/hukum/nN9rlaEb-kerugian-negara-akibat-korupsi-mencapai-rp168triliun diakses 21-11-2020
} 
tersebut, pengembalian aset hasil tindak pidana korupsi guna pengembalian kerugian keuangan negara faktanya tidak banyak berhasil. ${ }^{4}$

Undang-Undang Nomor 7 Tahun 2006 tentang Ratifikasi Konvensi Anti Korupsi (UNCAC) 2003 mengatur bahwa pengembalian aset dapat dilakukan melalui jalur pidana (aset recovery secara tidak langsung melalui criminal recovery) dan jalur perdata (aset recovery secara langsung melalui civil recovery). Mahkamah Agung Republik Indonesia sebagai lembaga negara pemegang kekuasaan kehakiman perlu mengupayakan terwujudnya pemulihan aset (asset recovery) sebagai tindakan negara terhadap kekayanannya yang diambil koruptor melalui perbuatan pidana. Pada tanggal 24 Juli 2020 telah diundangkan Peraturan Mahkamah Agung Nomor 1 Tahun 2020 tentang Pedoman Pemidanaan Pasal 2 dan Pasal 3 Undang-Undang Pemberantasan Tindak Pidana Korupsi melalui Berita Negara Republik Indonesia Tahun 2020 Nomor 832. PERMA ini wajib dijadikan pedoman bagi hakim agar tidak terjadi disparitas putusan perkara yang memiliki karakter serupa, tanpa mengurangi kemandirian hakim.

Sesuai teori Gustav Radburg bahwa tujuan hukum itu adalah adanya keadilan, kepastian, dan kemanfaatan hukum, seharusnya tujuan hukum akan dapat diwujudkan melalui pemidanaan yang didasarkan pembuktian perhitungan kerugian keuangan negara guna pengembalian aset hasil tindak pidana. Setiap penjatuhan pidana harus dilakukan dengan memperhatikan kepastian dan proporsionalitas pemidanaan untuk mewujudkan keadilan, demikian dalam konsideran PERMA tersebut disebutkan. Namun demikian, implikasi Peraturan Mahkamah Agung Nomor 1 Tahun 2020 belum dapat diketahui dan diperkirakan bagaimana analisis yuridis pembentukan pedoman pemidanaan dalam Peraturan Mahkamah Agung Nomor 1 Tahun 2020 terhadap pengembalian kerugian keuangan negara hasil tindak pidana korupsi. Hal ini menarik untuk dikaji guna mendapatkan formulasi kebijakan hukum ius constituendum yang dapat menjamin keadilan sosial bagi seluruh rakyat Indonesia.

\section{Metode Penelitian}

Penelitian ini merupakan penelitian hukum normatif (atau dinamakan penelitian yuridis normatif) dengan pendekatan perundang-undangan (statute approach) dan pendekatan kasus (case approach). Penelitian hukum normatif digunakan untuk mengkaji peraturan perundang-perundangan, putusan-putusan pengadilan terkait implikasi Peraturan Mahkamah Agung RI Nomor 1 Tahun 2020 terhadap pemidanaan guna pengembalian kerugian keuangan negara hasil tindak pidana korupsi. Penelitian ini didukung dengan literatur-literatur yang terkait dengan masalah yang diteliti. Penelitian ini menggunakan data sekunder, yakni berupa bahan hukum yang diambil dengan cara penelitian pustaka. Bahan hukum yang diambil dari studi kepustakaan terdiri atas bahan hukum primer, bahan hukum sekunder, dan bahan hukum tersier, serta bahan non hukum. Penelitian normatif menggunakan pendekatan perundang-undangan, karena meneliti berbagai aturan hukum yang menjadi fokus sentral penelitian, yakni Peraturan Mahkamah Agung RI Nomor 1 Tahun 2020.

\section{Hasil dan Pembahasan}

Mahkamah Agung telah mengeluarkan Peraturan Mahkamah Agung Nomor 1 Tahun 2020 tentang Pedoman Pemidanaan Pasal 2 dan Pasal 3 Undang-Undang Pemberantasan Tindak Pidana Korupsi. Peraturan Mahkamah Agung (PERMA) ini dilatarbelakangi adanya permasalahan disparitas putusan, khususnya disparitas pidana pada perkara-perkara korupsi. Menyadari itu, sejalan dengan kebijakan Mahkamah Agung membangun sistem kamar yang salah satu tujuannya adalah bagaimana mewujudkan adanya kesatuan penerapan hukum dalam perkara-perkara yang sejenis dan serupa.

Peraturan Mahkamah Agung merupakan salah satu produk hukum yang diterbitkan Mahkamah Agung Republik Indonesia. Produk hukum Mahkamah Agung antara lain Peraturan Mahkamah Agung (PERMA), Surat Edaran Mahkamah Agung (SEMA), Fatwa, dan Surat Keputusan Ketua Mahkamah Agung (SK KMA). PERMA pada dasarnya merupakan bentuk peraturan yang berisi ketentuan bersifat hukum

\footnotetext{
${ }^{4}$ Bettina Yahya, Budi Suhariyanto, dan Muh. Ridha Hakim, 2017, Urgensi dan Mekanisme Pengembalian Aset Hasil Tindak Pidana Korupsi, Laporan Penelitian, Jakarta, Puslitbang Hukum dan Peradilan Mahkamah Agung RI, 2017, hlm. pengantar.
} 
acara, sedangkan SEMA merupakan bentuk edaran pimpinan Mahkamah Agung kepada seluruh jajaran peradilan yang berisi bimbingan dalam penyelenggaraan peradilan yang lebih bersifat administrasi. Sementara itu, Fatwa Mahkamah Agung merupakan pendapat hukum Mahkamah Agung yang diberikan atas permintaan lembaga negara. Kemudian, SK KMA dijelaskan sebagai surat keputusan (beschikking) yang dikeluarkan Ketua MA mengenai suatu hal tertentu. ${ }^{5}$

Kedudukan PERMA Nomor 1 Tahun 2020 tentang Pedoman Pemidanaan Pasal 2 dan Pasal 3 Undang-Undang Pemberatasan Tindak Pidana Korupsi dalam sistem hukum adalah sebagai bagian dari substansi hukum (legal substance). Menurut Lawrence M. Friedman sistem hukum tersusun dari subsistem-subsistem yang berupa substansi hukum (legal substance), struktur hukum (legal structure), dan budaya hukum (legal culture). Ketiga subsistem ini sangat menentukan berjalannya hukum. Substansi hukum menyangkut aspek-aspek pengaturan hukum atau peraturan perundang-undangan. Struktur hukum meliputi aparatur penegak hukum serta sarana prasarana hukum itu sendiri, sedangkan budaya hukum menyangkut perilaku masyarakatnya. ${ }^{6}$ PERMA Nomor 1 Tahun 2020 menjadi komponen substansi hukum dalam sistem peradilan pidana Indonesia. PERMA Nomor 1 Tahun 2020 sebagai faktor hukumnya atau substansi hukum menjadi unsur pokok dalam penegakan hukum. PERMA ini dapat menjadi ujung tombak pengembalian kerugian keuangan negara dari hasil tindak pidana korupsi melalui instrumen pengadilan.

PERMA Nomor 1 Tahun 2020 hanya mengatur perkara tindak pidana korupsi yang melanggar Pasal 2 dan/atau Pasal 3 Undang-Undang Pemberantasan Tindak Pidana Korupsi. Pasal lainnya tidak terikat dengan PERMA pedoman pemidanaan ini. Sesuai asas legalitas, PERMA ini hanya mengikat perkara Pasal 2 dan 3 setelah PERMA diundangkan, yakni berlaku setelah tanggal 24 Juli 2020. Asas legalitas membatasi bahwa tidak ada suatu perbuatan yang dapat dipidana kecuali telah ada ketentuan perundang-undangan sebelumnya yang mengatur bahwa perbuatan tersebut merupakan tindak pidana. Prof. Moeljanto menerangkan bahwa asas legalitas (principle of legality) ialah asas yang menentukan bahwa tidak ada perbuatan yang dilarang dan diancam dengan pidana jika tidak ditentukan terlebih dahulu dalam perundang-undangan. Dalam bahasa Latin, asas legalitas dikenal sebagai Nullum delictum nulla poeba sine praevia lege poenale (tidak ada delik, tidak ada pidana tanpa peraturan lebih dahulu). ${ }^{7}$

Peraturan Mahkamah Agung RI Nomor 1 Tahun 2020 tentang Pedoman Pemidanaan Pasal 2 dan Pasal 3 Undang-Undang Pemberantasan Tindak Pidana Korupsi terdiri atas 3 (tiga) huruf konsideran, 7 (tujuh) angka dasar hukum, dan 23 (dua puluh tiga) pasal. Peraturan terobosan Mahkamah Agung ini tersusun dari 27 (dua puluh tujuh) halaman termasuk lampirannya. Peraturan Mahkamah Agung RI Nomor 1 Tahun 2020 hanya mengatur Pasal 2 dan Pasal 3, karena hanya pedoman menjatuhkan pidana, tidak termasuk menentukan kesalahan terdakwa, apakah memenuhi unsur delik atau tidak. Adapun pedoman yang dimaksud terdapat pada Lampiran Peraturan Mahkamah Agung RI Nomor 1 Tahun 2020.

Pedoman pemidanaan yang dimuat dalam lampiran PERMA ini ditampilkan menjadi 6 (enam) tahap. Tahap I sesuai Pasal 6; Tahap II berdasarkan Pasal 7 sampai dengan Pasal 11; Tahap III memilih rentang penjatuhan pidana sesuai Pasal 12; Tahap IV merujuk Pasal 13 dan Pasal 14; dan Tahap V berdasarkan Pasal 15 sampai dengan Pasal 17, serta tahap VI sesuai pengaturan Pasal 18 dan Pasal 19 PERMA tersebut.

Adapun penjelasan tahapan pedoman pemidanaan sesuai Lampiran PERMA Nomor 1 Tahun 2020 tentang Pedoman Pemidanaan Pasal 2 dan Pasal 3 Undang-Undang Pemberantaan Tindak Pidana Korupsi sebagai berikut:

1) Tahap I

Tahap I ialah tahap menentukan kategori kerugian keuangan negara atau perekonomian negara. Tahap ini didasarkan pada Pasal 6 PERMA Nomor 1 Tahun 2020. Caranya dengan memilih atau memberikan ceklis pada pilihan kategori yang sesuai perkara. Apabila Pasal yang didakwakan Pasal 2 UU

5https://m.hukumonline.com/klinik/detail/ulasan/cl6102/kekuatan-hukum-produk-produk-hukumma-PERMA --sema--fatwa--sk-kma/ diakses 29-11-2020 jam 21.00 WIB.

${ }^{6}$ Lawrence M. Friedman, 1975, The Legal System: A Social Science Perspective, New York, Russel Sage Foundation, hlm. 11.

${ }^{7}$ Moeljanto, 2008, Asas-Asas Hukum Pidana, Jakarta, Rineka Cipta, hlm. 25. 
Pemberantasan Tindak Pidana Korupsi (PTPK), maka pedomannya ada pada Pasal 6 ayat (1), sedangkan apabila mengadili Pasal 3 UU PTPK, maka mengacu pada Pasal 6 ayat (2) PERMA ini.

Kategori kerugian keuangan negara atau perekonomian negara berdasarkan Pasal 6 ayat (1) terbagi ke dalam 4 (empat) kategori sebagai berikut:

a. Kategori Paling Berat, yakni jika nilai kerugian keuangan negara atau perekonomian negara dari tindak pidana korupsi lebih dari Rp100.000.000.000,00 (seratus miliar rupiah);

b. Kategori Berat, yakni jika nilai kerugian keuangan negara atau perekonomian negara dari tindak pidana korupsi lebih dari Rp25.000.000.000,00 (dua puluh lima miliar rupiah) sampai dengan Rp100.000.000.000 (seratus miliar rupiah);

c. Kategori Sedang, yakni jika nilai kerugian keuangan negara atau perekonomian negara dari tindak pidana korupsi lebih dari Rp1.000.000.000,00 (satu lima miliar rupiah) sampai dengan Rp25.000.000.000,00 (dua puluh lima miliar rupiah);

d. Kategori Ringan, yakni jika nilai kerugian keuangan negara atau perekonomian negara dari tindak pidana korupsi lebih dari Rp200.000.000,00 (dua ratus juta rupiah) sampai dengan Rp1.000.000.000,00 (satu lima miliar rupiah).

Apabila pasal yang diadili adalah Pasal 3 UU PTPK, maka penghitungannya menggunakan Pasal 6 ayat (2). Kategori kerugian keuangan negara atau perekonomian negara berdasarkan Pasal 6 ayat (2) terbagi ke dalam 4 (empat) kategori sebagai berikut:

a. Kategori Paling Berat, yakni jika nilai kerugian keuangan negara atau perekonomian negara dari tindak pidana korupsi lebih dari Rp100.000.000.000,00 (seratus miliar rupiah);

b. Kategori Berat, yakni jika nilai kerugian keuangan negara atau perekonomian negara dari tindak pidana korupsi lebih dari Rp25.000.000.000,00 (dua puluh lima miliar rupiah) sampai dengan Rp100.000.000.000,00 (seratus miliar rupiah);

c. Kategori Sedang, yakni jika nilai kerugian keuangan negara atau perekonomian negara dari tindak pidana korupsi lebih dari Rp1.000.000.000,00 (satu lima miliar rupiah) sampai dengan Rp25.000.000.000,00 (dua puluh lima miliar rupiah);

d. Kategori Ringan, yakni jika nilai kerugian keuangan negara atau perekonomian negara dari tindak pidana korupsi lebih dari Rp200.000.000,00 (dua ratus juta rupiah) sampai dengan Rp1.000.000.000,00 (satu lima miliar rupiah).

e. Kategori Paling Ringan, yakni jika nilai kerugian keuangan negara atau perekonomian negara dari tindak pidana korupsi sampai dengan Rp200.000.000,00 (dua ratus juta rupiah).

\section{2) Tahap II}

Tahap II ialah tahap menentukan tingkat kesalahan, dampak, dan keuntungan. Tahap ini didasarkan pada Pasal 7 sampai dengan Pasal 11 PERMA Nomor 1 Tahun 2020. Caranya sama, yakni dengan memilih atau memberikan ceklis pada pilihan tingkatan yang sesuai perkara.

Tingkat kesalahan, dampak, dan keuntungan dibagi dalam 3 (tiga) kategori, yaitu tingkat kesalahan, dampak, dan keuntungan tinggi; tingkat kesalahan, dampak, dan keuntungan sedang; dan tingkat kesalahan, dampak, dan keuntungan rendah. Aspek-aspek yang ditentukan pada masing-masing tingkat kesalahan, dampak, dan keuntungan dijabarkan dengan prasyarat dalam Lampiran PERMA Nomor 1 Tahun 2020.

a. Tingkat Kesalahan, Dampak, dan Keuntungan Tinggi (berdasarkan Pasal 8 PERMA Nomor 1 Tahun 2020).

(1). Aspek kesalahan tinggi, sesuai Pasal 8 huruf a, dengan klasifikasi:

a) Terdakwa memiliki peran yang paling signifikan dalam terjadinya tindak pidana korupsi, baik dilakukan sendiri maupun bersama-sama; 
b) Terdakwa memiliki peran sebagai penganjur atau yang menyuruhlakukan terjadinya tindak pidana korupsi; terdakwa melakukan perbuatannya dengan menggunakan modus operandi atau sarana/teknologi canggih; dan atau

c) Terdakwa melakukan perbuatannya dalam keadaan bencana atau krisis ekonomi skala nasional.

(2). Aspek dampak tinggi, sesuai Pasal 8 huruf b PERMA, dengan klasifikasi:

a) Perbuatan terdakwa mengakibatkan dampak atau kerugian dalam skala nasional;

b) Perbuatan terdakwa mengakibatkan hasil pekerjaan atau pengadaan barang dan/atau jasa sama sekali tidak dapat dimanfaatkan; dan/atau

c) Perbuatan terdakwa mengakibatkan penderitaan bagi kelompok masyarakat yang rentan, diantaranya orang lanjut usia, anak-anak, fakir miskin, peremouan hamil, dan penyandang disabilitas.

(3). Aspek keuntungan terdakwa tinggi, berdasarkan Pasal 8 huruf c, yakni dengan indikator:

a) Nilai harta benda yang diperoleh terdakwa dari tindak pidana korupsi besarnya lebih dari $50 \%$ (lima puluh persen) dari kerugian keuangan negara atau perekonomian negara dalam perkara yang bersangkutan; dan/atau

b) Nilai pengembalian kerugian keuangan negara yang dilakukan terdakwa besarnya kurang dari $10 \%$ (sepuluh persen) dari nilai harta benda yang diperoleh terdakwa dalam perkara yang bersangkutan.

b. Tingkat Kesalahan, Dampak, dan Keuntungan Sedang (berdasarkan Pasal 9 PERMA Nomor 1 Tahun 2020).

(1). Aspek kesalahan sedang, sesuai Pasal 9 huruf a, dengan kriteria:

a) Terdakwa memiliki peran yang signifikan dalam terjadinya tindak pidana korupsi, baik dilakukan sendiri maupun bersama-sama;

b) Terdakwa merupakan orang yang turut serta melakukan tindak pidana korupsi;

c) Terdakwa melakukan perbuatannya dengan disertai atau didahului perencanaan tanpa modus operandi atau sarana/teknologi canggih; dan atau

d) Terdakwa melakukan perbuatannya dalam keadaan bencana atau krisis ekonomi skala daerah/lokal.

(2). Aspek dampak sedang, sesuai Pasal 9 huruf b PERMA, dengan ciri-ciri:

a) Perbuatan terdakwa mengakibatkan dampak atau kerugian dalam skala provinsi; dan atau

b) Perbuatan terdakwa mengakibatkan hasil pekerjaan atau pengadaan barang dan/atau jasa tidak dapat dimanfaatkan secara sempurna sehingga membutuhkan penambahan anggaran negara untuk perbaikan atau penyelesaian; dan/atau

(3). Aspek keuntungan terdakwa sedang, berdasarkan Pasal 9 huruf c, yakni dengan indikator:

a) Nilai harta benda yang diperoleh terdakwa dari tindak pidana korupsi besarnya $10 \%$ (lima puluh persen) sampai dengan 50\% (lima puluh persen) dari kerugian keuangan negara atau perekonomian negara dalam perkara yang bersangkutan; dan/atau

b) Nilai pengembalian kerugian keuangan negara yang dilakukan terdakwa besarnya dari $10 \%$ (sepuluh persen) persen) sampai dengan 50\% (lima puluh persen) dari nilai harta benda yang diperoleh terdakwa dalam perkara yang bersangkutan.

c. Tingkat Kesalahan, Dampak, dan Keuntungan Rendah (berdasarkan Pasal 10 PERMA Nomor 1 Tahun 2020).

(1). Aspek kesalahan rendah, sesuai Pasal 10 huruf a, dengan kriteria:

a) Terdakwa memiliki peran yang tidak siginifikan dalam terjadinya tindak pidana korupsi; 
b) Terdakwa merupakan orang yang membantu dalam pelaksanaan tindak pidana korupsi;

c) Terdakwa melakukan perbuatannya karena kurang pemahaman mengenai dampak dari perbuatannya; dan/atau

d) Terdakwa melakukan perbuatannya tidak dalam keadaan bencana atau krisis ekonomi.

(2). Aspek dampak rendah, sesuai Pasal 10 huruf b PERMA, dengan ciri-ciri:

a) Perbuatan terdakwa mengakibatkan dampak atau kerugian dalam skala kabupaten/kota atau satuan wilayah di bawah kabupaten/kota; dan/atau

b) Perbuatan terdakwa mengakibatkan hasil pekerjaan atau pengadaan barang dan/atau jasa tidak sesuai spesifikasi tanpa pertanggungjawaban yang jelas namun masih dapat dimanfaatkan.

(3). Aspek keuntungan terdakwa rendah, berdasarkan Pasal 10 huruf c, yakni dengan indikator:

a) Nilai harta benda yang diperoleh terdakwa dari tindak pidana korupsi besarnya kurang dari $10 \%$ (lima puluh persen) dari kerugian keuangan negara atau perekonomian negara dalam perkara yang bersangkutan; dan/atau

b) Nilai pengembalian kerugian keuangan negara yang dilakukan terdakwa besarnya lebih dari $50 \%$ (lima puluh persen) dari nilai harta benda yang diperoleh terdakwa dalam perkara yang bersangkutan.

Setelah memilih tingkat kesalahan, dampak, dan keuntungan terdakwa, maka keseluruhan pemilihan tersebut dijumlahkan. Ada berapa yang termasuk tinggi, ada berapa yang tingkat sedang, dan berapa yang termasuk kategori rendah. Hakim menentukan tingkat kesalahan, dampak, dan keuntungan dengan memperhatikan jumlah aspek kesalahan, dampak, dan keuntungan yang paling banyak. Yakni dengan memilih berdasarkan kriteria tingkat peranan terdakwa (kesignifikanan), posisi peranan terdakwa (penganjur/ turut serta/ membantu), modus operandi (sarana/teknologi canggih), keadaan negara (bencana/krisis ekonomi), skala cakupan dampak (nasional/lokal), kemanfaatan hasil (manfaat Barang Milik Negara yang dikorupsi), penderitaan masyarakat rentan, nilai keuntungan yang didapat, pengembalian kerugian keuangan negara yang dilakukan terdakwa. Contohnya, total aspek kesalahan, dampak, dan keuntungan tercatat tingkat tinggi dengan perbandingan jumlah tinggi : sedang : rendah sama dengan 5:3:1, maka hakim harus memilih tingkat kesalahan, dampak, dan keuntungan terdakwa adalah pada tingkat tinggi. Dalam hal suatu perkara memiliki aspek kesalahan, dampak, dan keuntungan yang tersebar secara merata pada beberpa atau seluruh kategori, hakim menentukan tingkat kesalahan, dampak, dan keuntungan berada pada tingkat sedang.

3) Tahap III

Tahap III disebut tahap memilih Rentang Penjatuhan Pidana yang didasarkan pada Pasal 12 PERMA Nomor 1 Tahun 2020. Hakim memilih rentang penjatuhan pidana dengan menyesuaikan antara:

a. kategori kerugian keuangan negara atau perekonomian negara sebagaimana dimaksud dalam Pasal 6 (Tahap I); dan

b. tingkat kesalahan, dampak, dan keuntungan sebagaimana dimaksud dalam Pasal 7 (Tahap II).

Pasal 12 PERMA Nomor 1 Tahun 2020 memberikan tabel Matrik Rentang Penjatuhan Pidana. Tabel matrik memuat batasan pidana penjara dan pidana denda yang dapat dijatuhkan hakim.

Kategori Paling Ringan dalam Matrik Rentang Penjatuhan Pidana hanya berlaku untuk Pasal 3 Undang-Undang Pemberantasan Tindak Pidana Korupsi. Pasal 3 UU PTPK menyebutkan, "Setiap orang yang dengan tujuan menguntungkan diri sendiri atau orang lain atau suatu korporasi, menyalahgunakan kewenangan, kesempatan atau sarana yang ada padanya karena jabatan atau kedudukan yang dapat merugikan keuangan negara atau perekonomian negara, dipidana dengan pidana penjara seumur hidup atau pidana penjara paling singkat 1 (satu) tahun dan paling lama 20 (dua puluh) tahun dan atau denda paling sedikit Rp. 50.000.000,00 (lima puluh juta rupiah) dan paling banyak Rp. 1.000.000.000,00 (satu milyar rupiah)." 
4) Tahap IV

Tahap IV diatur berdasarkan Pasal 13 dan 14 PERMA Nomor 1 Tahun 2020. Dalam menjatuhkan pidana, hakim harus mempertimbangkan keadaan-keadaan yang memberatkan dan meringankan dengan memperhatikan sifat yang baik dan jahat dari terdakwa.

Adapun keadaan yang memberatkan atau meringankan meliputi keadaan sebagai berikut:

a. Keadaan yang memberatkan antara lain:

a) terdakwa pernah melakukan tindak pidana sebelumnya;

b) terdakwa tidak kooperatif dalam menjalani proses peradilan;

c) terdakwa mencoba menghilangkan/ menyembunyikan/ merusak alat bukti;

d) terdakwa merupakan aparat penegak hukum atau aparatur sipil negara.

b. Keadaan yang meringankan antara lain:

a) terdakwa belum pernah;

b) terdakwa kooperatif dalam menjalani proses peradilan;

c) terdakwa menyesali perbuatannya dan berjanji tidak mengulangi lagi perbuatan pidana;

d) terdakwa memberi keterangan secara berterus terang dalam persidangan;

e) terdakwa telah menyerahkan diri atau melaporkan tindak pidana yang dilakukannya;

f) terdakwa belum menikmati hasil tindak pidana;

g) terdakwa telah berusia lanjut atau dalam kondisi sakit;

h) terdakwa mengembalikan harta benda yang diperoleh dari tindak pidana korupsi secara sukarela sebelum pengucapan putusan; dan/atau

i) terdakwa memiliki keadaan ekonomi/finansial yang buruk.

Pada tahap IV ini hakim dapat mempertimbangkan keadaan-keadaan yang memberatkan dan meringankan lainnya yang bersifat kasuistis berdasarkan fakta persidangan selain yang diatur dalam daftar indikator di atas.

\section{5) Tahap V}

Tahap V tahapan langkah pemidanaan berpedoman berdasarkan Pasal 15 dan 17 PERMA tersebut. Tahap $\mathrm{V}$ disebut Tahap Menjatuhkan Pidana. Hakim harus menjatuhkan pidana berdasarkan Rentang Penjatuhan Pidana yang telah dipilih pada Tahap III dengan mempertimbangkan keadaan-keadaan yang memberatkan dan meringankan. Dalam hal tindak pidana dilakukan dalam keadaan tertentu sebagaimana dimaksud Pasal 2 ayat (2) UU PTPK, hakim dapat menjatuhkan pidana mati sepanjang perkara tersebut memiliki tingkat kesalahan, dampak, dan keuntungan tinggi. Sebaliknya, hakim dapat tidak menjatuhkan pidana denda dalam hal kerugian keuangan negara atau perekonomian negara di bawah Rp50.000.000,00 (lima puluh juta rupiah).

6) Tahap VI

Tahap VI ini merupakan Tahap Mempertimbangkan Ketentuan Lain yang Berkaitan dengan Penjatuhan Perkara yang didasarkan Pasal 18 dan 19 PERMA tersebut.

Hakim harus mempertimbangkan ketentuan lain yang berkaitan dengan penjatuhan pidana. Ketentuan lain itu terdiri dari namun tidak terbatas pada:

a. Status terdakwa sebagai saksi pelaku yang bekerjasama mengungkapkan tindak pidana dengan aparat penegak hukum; dana tau

b. Terdakwa terbukti bersalah melakukan tindak pidana korupsi sebagaimana dimaksud dalam Pasal 2 atau Pasal 3 Undang-Undang Pemberantasan Tindak Pidana Korupsi dan tindak pidana lainnya secara kumulatif yang diadili dalam satu berkas perkara. 
Pedoman pemidanaan dalam PERMA Nomor 1 Tahun 2020 tidak mengecualikan ketentuan mengenai gabungan tindak pidana yang diatur dalam peraturan perundang-undangan. Pedoman pemidanaan juga tidak mengurangi kewenangan hakim untuk menjatuhkan pidana tambahan lainnya sesuai dengan ketentuan peraturan perundang-undangan.

PERMA Nomor 1 Tahun 2020 menjadi aturan wajib yang harus dilaksanakan hakim pengadilan tindak pidana korupsi dalam tahapan pertimbangan putusan, meskipun tidak mengurangi kemandirian hakim. Pedoman ini sebenarnya mempermudah hakim dalam menjatuhkan putusan, sekaligus menjadi batasan agar tidak terjadi disparitas putusan pemidanaan. Sejalan dengan asas hukum bahwa hakim dianggap tahu, maka upaya Mahkamah Agung mengisi kekosongan hukum dalam hal pedoman pemidanaan menjadi terobosan dan petunjuk bagi hakim yang melaksanakan persidangan guna menjatuhkan putusan yang lebih berkeadilan.

Law is a tool of social engineering. Dengan membuat aturan hukum, akan dapat mengatur masyarakat ke arah tertentu. Sasaran PERMA Nomor 1 Tahun 2020 tidak lain ialah agar tidak terjadi disparitas pemidanaan perkara korupsi terkait amar pidana dan denda maupun uang pengganti kaitannya dengan pengembalian kerugian keuangan negara. Dengan interpretasi yang sama antarhakim dan antarpenegak hukum terkait, maka akan lebih mengefektifkan pemberantasan korupsi di Indonesia. Upaya pengembalian akan dapat dilakukan lebih maksimal sehingga pada ujungnya akan dapat mewujudkan sila kelima Pancasila yakni keadilan sosial bagi seluruh rakyat Indonesia. Sebagai negara yang menjunjung nilai-nilai ketuhanan sesuai sila pertama Pancasila yakni Ketuhanan Yang Maha Esa, tindakan meresapi kaidah keagaman dapat menjadi instrumen alternatif untuk mencegah tindakan koruptif.

Apabila dilihat dari sudut pendekatan nilai, pembaharuan hukum pidana pada hakikatnya merupakan upaya melakukan peninjauan dan penilaian kembali (reorientasi dan re-evaluasi) nilai-nilai sosiopolitik, sosiofilosofis, dan sosiokultural yang mendasari dan memberikan isi terhadap muatan normatif dan substantif hukum pidana yang dicita-citakan (ius constituendum). ${ }^{8}$ PERMA Nomor 1 Tahun 2020 meninjau dan mengevaluasi adanya perbedaan penjatuhan pidana penjara, denda, dan uang pengganti pada putusan-putusan pengadilan tipikor.

Pelaksanaan putusan denda dan uang pengganti sebagai wujud nyata pengembalian kerugian keuangan negara hasil tindak pidana korupsi perlu mempertimbangkan perkembangan moneter dan ekonomi masyarakat karena nilainya mudah berubah. Menurut Prof. Barda Nawawi Arief, perlu dipikirkan kebijakan legislatif yang mencakup keseluruhan sistem sanksi pidana denda. Perlu dipertimbangkan mengenai sistem penetapan jumlah pidana denda, batas waktu pelaksanaan pembayaran denda, tindakan-tindakan paksaan yang diharapkan dapat menjamin dilakukannya pembayaran denda dalam hal terpidana tidak dapat membayar dalam batas waktu yang telah ditetapkan, pelaksanaan pidana denda dalam hal-hal tertentu, dan pedoman atau kriteria dalam menjatuhkan pidana denda. $^{9}$

Pembaharuan hukum pidana dalam menangai korupsi sebenarnya telah banyak dilakukan, yakni berupa adanya peradilan tindak pidana korupsi yang menggunakan ketentuan khusus yang memiliki hukum acara khusus pula. Akan tetapi pada pedoman pemidanaannya belum ada. PERMA Nomor 1 Tahun 2020 menjadi langkah awal dalam pembaharuan hukum pemidanaan perlu didukung dan dilaksanakan.

Sejalan dengan teori pembaharuan hukum, legislasi pemidanaan tindak pidana korupsi dalam PERMA Nomor 1 Tahun 2020 berada pada dimensi penciptaan. Perkembangan teknologi menimbulkan perkembangan kejahatan. Karena kejahatan dengan cara baru yang menggunakan teknologi telah terjadi sehingga dapat mengkorupsi aset negara, maka peraturan perundang-undangan harus diwujudkan sebagai usaha responsif dalam pemberantasan korupsi dengan pengembalian aset sebesar-besarnya. Mahkamah Agung sebagai lembaga negara yang telah melakukan pembangunan zona integritas untuk mewujudkan Wilayah Bebas dari Korupsi (WBK) dan Wilayah Birokrasi Bersih dan Melayani (WBBM) harus membuktikan keseriusan pemberantasan korupsi melalui pelaksanaan PERMA Nomor 1 Tahun 2020.

\footnotetext{
${ }^{8}$ Rusli Muhammad, Op. Cit., hlm. 5

9 Barda Nawawi Arief, Teori-teori dan Kebijakan Pidana, Bandung, Alumni, 2005, hlm. 181-182.
} 


\section{Simpulan}

Analisis yuridis pembaharuan hukum pembentukan pedoman pemidanaan dalam Peraturan Mahkamah Agung Nomor 1 Tahun 2020 terhadap disparitas putusan pengembalian kerugian keuangan negara hasil tindak pidana korupsi ialah Peraturan Mahkamah Agung berkedudukan sebagai substansi hukum dalam pemidanaan tindak pidana korupsi yang ditujukan sebagai pedoman penentuan besar kecilnya pidana yang dijatuhkan dengan mempertimbangkan kerugian keuangan negara, tingkat kesalahan, dampak, dan keuntungan. Terdapat 6 (enam) tahapan pedoman pemidanaan dalam PERMA ini. Ukuran pemidanaan telah mempertimbangan aspek ekonomi dalam hukum. Seyogyanya hakim, jaksa, dan penyidik, serta aparatur terkait agar mendalami dan mendukung Peraturan Mahkamah Agung Nomor 1 Tahun 2020 sebagai upaya responsif atas perkembangan tindak pidana korupsi sehingga pengembalian aset ke kas negara lebih maksimal dan disparitas putusan tidak terjadi lagi.

\section{Daftar Pustaka}

Andi Hamzah, 1993, Sistem Pidana dan Pemidanaan Indonesia, Jakarta, Pradnya Paramita.

Barda Nawawi Arief, Teori-teori dan Kebijakan Pidana, Bandung, Alumni, 2005.

Bettina Yahya, Budi Suhariyanto, dan Muh. Ridha Hakim, 2017, Urgensi dan Mekanisme Pengembalian Aset Hasil Tindak Pidana Korupsi, Laporan Penelitian, Jakarta, Puslitbang Hukum dan Peradilan Mahkamah Agung RI, 2017, hlm. pengantar.

Djoko Prakoso, 1988, Surat Dakwaan, Tuntutan Pidana dan Eksaminasi Perkara di dalam Proses Pidana, Yogyakarta, Liberty.

E. Utrecht, 1958, Hukum Pidana I, Jakarta, Universitas Indonesia.

Harrys Pratama Teguh, 2019, Hukum Keuangan Negara, Bandung, Pustaka Setia.

https://m.hukumonline.com/klinik/detail/ulasan/cl6102/kekuatan-hukum-produk-produk-hukum-maPERMA --sema--fatwa--sk-kma/ diakses 29-11-2020 jam 21.00 WIB.

https://nasional.kontan.co.id/news/ma-terbitkan-PERMA -12020-icw-hakim-yang-tidak-mengikutiharus-ada-sanksi diakses 28-11-2020

https://www.cnnindonesia.com/nasional/20200930124534-12-552660/icw-kerugian-negara-akibatkorupsi-rp392-t-di-2020 diakses 21-11-2020

https://www.medcom.id/nasional/hukum/nN9rlaEb-kerugian-negara-akibat-korupsi-mencapai-rp168triliun diakses 21-11-2020

Lawrence M. Friedman, 1975, The Legal System: A Social Science Perspective, New York, Russel Sage Foundation.

Leden Marpaung, 2008, Asas Teori dan Praktik Hukum Pidana, Jakarta, Sinar Grafika.

Moeljanto, 2008, Asas-Asas Hukum Pidana, Jakarta, Rineka Cipta.

Muhammad Ridha Basri, "Fikih Antikorupsi", Suara Muhammadiyah edisi tanggal 20 November 2020, diakses dari https://www.suaramuhammadiyah.id/2020/11/25/fikih-antikorupsi/, diakses 8 Januari 2021.

Muladi dan Barda Nawawi Arief, 1992, Teori dan Kebijakan Pidana, Bandung, Alumni.

Panduan Permasyarakataran Undang-Undang Dasar Negara Republik Indonesia Tahun 1945 Sesuai Urutan Bab, Pasal, dan Ayat, 2007, Jakarta, Sekretariat Jenderal MPR RI.

Peraturan Mahkamah Agung Nomor 1 Tahun 2020 tentang Pedoman Pemidanaan Pasal 2 dan Pasal 3 Undang-Undang Pemberantasan Tindak Pidana Korupsi.

Prasetyo, T., 2010, Kriminalisasi dalam Hukum Pidana. Bandung, Nusa Media.

R. Wiyono, 2008. Pembahasan Undang-Undang Pemberantasan Tindak Pidana Korupsi Edisi Kedua, Jakarta, Sinar Grafika. 
Pusat Kajian Hukum Pidana dan Kriminologi

Fakultas Hukum, Universitas Muhammadiyah Yogyakarta

E-mail: ijclc@umy.ac.id

Ronald, 2011, PERMA RI (Peraturan Mahkamah Agung Repulik Indonesia) Wujud Kerancuan antara Praktik Pembagian dan Pemisahan Kekuasaan, Jakarta, Rajawali Press.

Rusli Muhammad, 2019, Pembaharuan Hukum Pidana Indonesia, Yogyakarta, UII Press.

Sudarto, 1976, Tindak Pidana Korupsi di Indonesia, Semarang, Fakultas Hukum Universitas Diponegoro.

Syed Hussein Alatas, 1982, Sosiologi Korupsi: Sebuah Penjelajahan dengan Data Kontemporer, Jakarta, LP3ES.

Undang-Undang Dasar Negara RI Tahun 1945.

Yanuar P., 2015, Pengembalian Aset Hasil Korupsi, Bandung, Alumni. 